\title{
Financial Technology: Meningkatkan Inclusif Financial Emkm Di Era Pandemi Covid-19
}

\author{
Jamaluddin Majid \\ Jamalmajid75@gmail.com \\ Universitas Islam Negeri Alauddin Makassar
}

\begin{abstract}
This study aims to find out how the role of financial technology (fintech) in realizing financial inclusion for micro, small and medium-sized entities (EMKM) during the covid-19 pandemic which is currently endemic. The research method applied in this paper is a qualitative method by collecting data through literature study. The results of the study indicate that the Covid-19 pandemic indirectly affects the increase in the use of technology, including in the financial sector, by using fintech. In addition, Fintech provides easy access to various types of financial services, can reach all EMKM to remote areas, opens easier and faster access to business financing, and contributes to EMKM empowerment and the local economy in increasing EMKM financial inclusion.
\end{abstract}

Keywords: Financial Technology, Inclusive Finance, Micro Small and Medium Entities

\begin{abstract}
Abstrak
Penelitian ini bertujuan untuk mengetahui bagaimana peran financial technology (fintech) dalam mewujudkan inclusif financial bagi Entitas Mikro Kecil dan Menengah (EMKM) pada masa pandemi covid-19 yang tegah mewabah. Metode penelitian yang diterapkan dalam penulisan ini adalah metode kualitatif dengan mengumpulkan data melalui study literatur. Adapun hasil penelitian menunjukkan bahwa secara tidak langsung pandemi covid-19 berpengaruh terhadap peningkatan penggunaan teknologi termasuk dalam bidang keuangan yaitu dengan menggunakan fintech. Selain itu, Fintech memberikan kemudahan mengakses berbagai jenis layanan keuangan, dapat menjangkau seluruh EMKM hingga daerah yang terpencil, membuka akses pembiayaan usaha yang lebih mudah dan cepat, serta berkontribusi dalam pemberdayaan EMKM dan ekonomi lokal dalam meningkatkan inklusi keuangan EMKM.
\end{abstract}

Kata Kunci: Teknologi Keuangan, Keuangan Inklusif, Entitas Mikro Kecil dan Menengah

\section{PENDAhUluan}

Pada tanggal 2 Maret 2020 menjadi sejarah awal mula masuknya pandemi covid-19 di Indonesia setelah resmi di umumkan oleh Presiden Joko Widodo. Pandemi covid-19 ini tidak hanya menimbulkan bencana dari sisi kesehatan semata, akan tetapi pandemi ini juga telah menimbulkan kekacauan dari segi ekonomi. Mewabahnya pandemi covid-19 ini tidak hanya berdampak bagi usaha-usaha berskala besar semata, termasuk EMKM juga ikut terkena imbas dari covid-19 tersebut. Sebuah studi menyebutkan bahwa jika covid-19 membuat indonesia mengalami penurunan persentase ekonomi sebesar $0,1 \%$ pada tahun 2020 . Organisation for Economic Co-operation and Development (OECD) menyebutkan bahwa pandemi ini berimplikasi pada pada ancaman krisiss ekonomi yang cukup besar dengan ditandai berhentinya aktivitas produksi di berbagai negara, jatuhnya tinggkat konsumsi masyarakat, hilangnya kepercayaan konsumen, dan jatuhnya bursa saham yang pada akhirnya mengarah pada ketidak pastian (Nalini, 2021). Untuk meminimalisir resiko kesehatan dan perekonomian maka baik kantor swasta maupun kantor pemerintah menerapkan kebijakan bekerja dari rumah (work from home).

Beberapa pengusaha menilai bagaimana kebutuhan yang muncul terkait dengan krisis bisnis covid-19 dapat memengaruhi bisnis mereka dan mengambil tindakan yang tepat, dengan mempertimbangkan juga beberapa aspek kompetitif seperti perencanaan skenario, analisis pemangku kepentingan, pengembangan strategi, komunikasi eksternal dan internal. Beberapa 
indikator dapat digunakan di perusahaan untuk mengevaluasi kapasitas reaktifnya dan memahami kemungkinan dampak perubahan digital untuk mengurangi efek negatif dari masalah krisis covid-19. Setelah latar belakang teoretis jelas, dan begitu analisis status eksternal dan internal telah dilakukan, EMKM harus merefleksikan model bisnis mereka sendiri. Dimasa pandemi covid-19 saat ini EMKM mengalami suatu kendala perekonomian yang cukup serius. Maka dari itu untuk mengatasi dampak tersebut perlunya diterapkan kebijakan-kebijakan dan pengimplementasian yang sesuai. Munculnya suatu fenomena baru yakni revolusi industri 4.0 dan terbatasnya ruang gerak akibat pandemi menyebabkan segala sistem perekonomian yang pada awalnya adalah sistem konvensional mau tidak mau harus dialihkan pada sistem virtual. Dimana segala kugiatan maupun tingkah laku manusia diikat oleh perkembangan teknologi di era pandemi agar perekonomian dapat terus berjalan (Ilham, 2020).

Diera revolusi induatri 4.0 perkembangan teknologi tentu sangat pesat, tidak hanya di Indonesia tetapi dunia juga merasakan perkembangan teknologi yang setiap waktunya berubah secara signifikan. Indonesia disebut sebagai negara yang menempati posisi keenam sebagai negara dengan penggunaan teknologi terbesar di dunia pada tahun 2013-2018. Hal tersebut dapat terjadi karena teknologi yang setiap harinya berkembang dengan pesat dan telah memasuki di berbagai sektor, salah satunya yaitu pada sektor keuangan. Transformasi digital tidak hanya berarti memperkenalkan teknologi baru untuk melakukan aktivitas yang ada: itu adalah proses mendesain ulang seluruh model bisnis (Nalini, 2021). Demi mendukung usaha pengusaha dalam mengimplementasik model bisnis baru dan transformasi digital pada usaha mereka, penting bagi pemerintah untuk membuat kebijakan struktural untuk kepentingan jangka panjang. Kebijakan ini tidak saja digunakan untuk menghadapi pandemi covid-19 tapi juga era Industri 4.0 kedepannya. Contohnya yaitu fintech (financial technology) yang merupakan teknologi untuk mendukung layanan jasa keuangan. Perkembangan fintech banyak memunculkan inovasi aplikasi dalam layanan keuangan, seperti alat pembayaran, alat pinjaman dan lain-lain yang mulai terkenal pada masa digital ini.

Sektor fintech menjadi strategi yang sangat penting untuk memperluas inklusi keuangan serta meningkatkan kesejahteraan masyarakat. Keberadaan fintech semakin diuntungkan dengan masifnya penggunaan smartphone oleh masyarakat, bahkan hingga daerah pedesaan, menjadi sarana penghubung dan solusi bagi masyarakat yang selama ini sulit dijangkau oleh lembaga keuangan formal. Lewat penggunaan smartphone, masyarakat dapat menggunakan layanan finansial dengan mudah untuk memenuhi kebutuhannya atau menjaga keberlanjutan bisnisnya dalam upaya pemulihan ekonomi nasional yang mengalami perlambatan imbas meluasnya dampak pandemi covid-19. Kemunculan layanan pinjam meminjam berbasis teknologi adalah solusi bagi EMKM agar tetap eksis dan terus mendorong pertumbuhan ekonomi nasional ditengah pandemi covid-19 ini. Dimana, para pelaku EMKM pada dasarnya memiliki problem yang hampir sama yakni masalah permodalan. Pelaku bisnis bisa memanfaatkan fintech sebagai jalan untuk pembiayaan perusahaannya karena fintech tidak hanya berperan dalam pembiayaan modal usaha tetapi ada juga yang merambah ke berbagai aspek seperti layanan pembayaran digital juga pengatur keuanga (Sugiarti dkk, 2019).

Pendirian suatu unit usaha termasuk EMKM adalah untuk menghasilkan laba sebesarbesarnya bagi para pemilik dan demi kepuasan pemilik. Terlebih dalam kondisi ekonomi sekarang ini, jumlah unit usaha yang berlabelkan EMKM terus meningkat secara signifikan baik dari jumlah unit, kemampuan menyerap tenaga kerja, dan sumbangan yang mengalir untuk Produk Domestik Bruto (PDB). Entitas Mikro Kecil Menengah (EMKM), merupakan salah satu pendorong penguatan serta pembangunan ekonomi dunia. Peran dan kontribusi EMKM cukup signifikan dalam perekonomian nasional terutama dalam penyerapan tenaga kerja hingga 77.678 .498 ribu orang atau sebesar $96.77 \%$ dari total tenaga kerja yang mampu diserap oleh usaha kecil, menengah dan besar.

Secara umum tujuan dari terciptanya fintech adalah untuk menarik perhatian dan minat konsumen dengan produk-produk yang ditawarkan yang menjajikan kemudahan dalam bidang keuangan. Dimana produk-produk yang ditawarkan bertujuan untuk mendorong pemerataan tingkat ekonomi penduduk, membantu pemenuhan kebutuhan pembiayaan maupun pinjaman bagi EMKM demi meningkatkan laba usaha. Berkaca dari sumbangsi besar EMKM bagi perekonomian suatu negara sehingga David McCleiland seorang sosiolog memberikan pandangannya terkait kemajuan suatu negara. Dimana, suatu bangsa ataupun negara dapat dikategorikan maju ketika negara tersebut setidaknya memiliki $2 \%$ total wirausaha dari populasi 
penduduknya (Mustaqim, 2020). Perkembangan potensi investasi era fintech terkhususnya di Indonesia memiliki potensi yang besar dan ini dapat dijadikan lonjakan bisnis keuangan di Indonesia yang harapanya dapat meningkatkan perekonomian masyarakat yang tengah prasejahtera hingga sekarang. Fintech memberi peluang baru yang nantinya dapat meningkatkan perekonomian masyarakat. karena pada dasarnya modal menjadi salah satu poin penting yang sangat memengaruhi perkembangan usaha (Ramadhona, 2018). Merujuk pada latar belakang di atas maka masalah dapat dirumuskan sebagai berikut:

Bagaimana peran fintech bagi keberlangsungan EMKM di era pandemi covid-19? Bagaimana peran fintech dalam mewujudkan inklusif financial bagi EMKM?

\section{Rerangka Pikir}

EMKM merupakan suatu entitas yang memiliki kontribusi yang sangat besar bagi pertumbuhan ekonmi suatu negara yang ikut terkena imbas akibat pandemi covid-19. Dimana segala aktivitas keseharian termasuk ekonomi harus beralih ke arah virtual. Salah satunya adalah dengan memanfaatkan salah satu teknologi yang berkembang di era revolusi industri 4.0 yakni financial technology. Financial technology dapat mempercepat inklusi keuangan karena financial technology membuka akses yang lebih besar ke layanan keuangan.

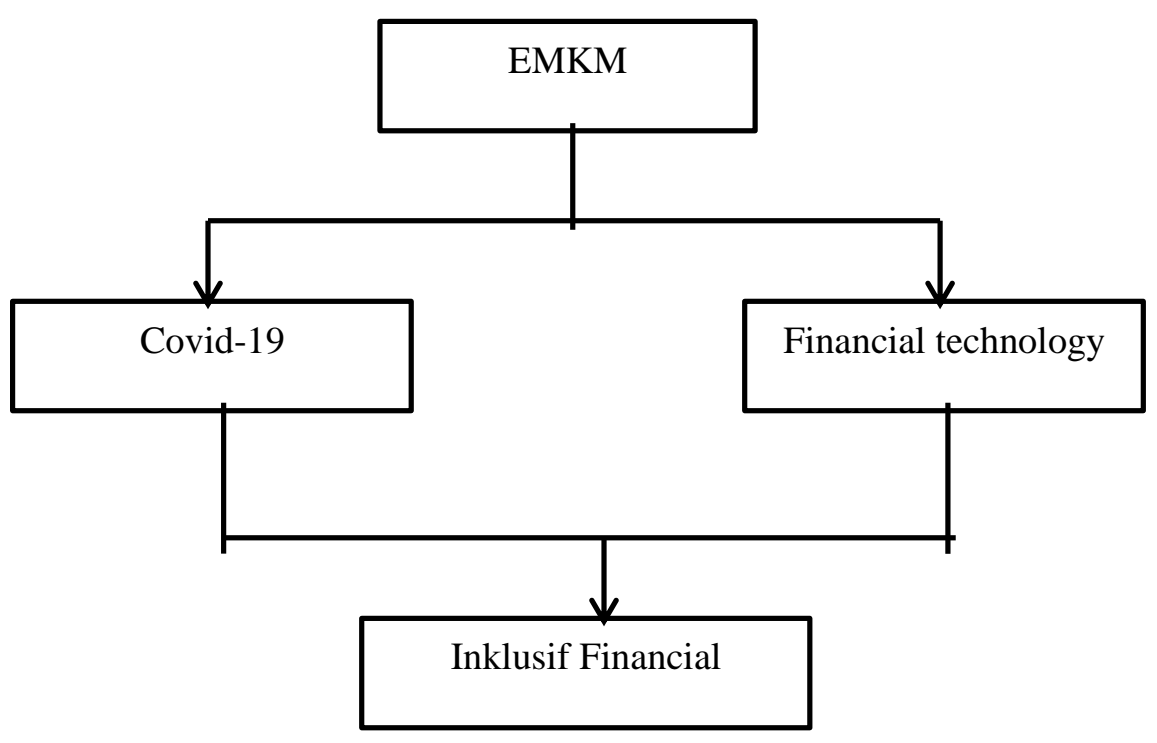

\section{METODE PENELITIAN}

Metode dalam penelitisan ini menggunakan metode kulitatif karena penelitian ini pada prinsipnya menerangkan, mendeskripsikan secara kritis, atau menggambarkan suatu fenomena, suatu kejadian atau suatu peristiwa interaksi sosial dalam masyarakat untuk mencari dan menemukan makna dalam konteks sesungguhnya (Gumilan, 2016 dalam Taufiq, 2020). Penelitian kualitatif merupakan penelitian yang bermaksud memahami fenomena tentang apa yang dialami oleh subyek penelitian misalnya perilaku, persepsi, motivasi, tindakan dapat lain secara holostic dan dengan cara deskripsi dalam bentuk kata-kata dan bahasa, pada suatu kontes khusus yang alamiah dan dengan memanfaatkan berbagai metode alamiah (Moleong, 2012). Penelitin kualitatif bertujuan untuk memahami realitas sosial, yaitu melihat suatu fenomena dari apa adanya, bukan fenomena yang seharusnya, kualitatif disebut sebagai suatu paradigma interaktif dan konstruktif, yang memandang realitas sosial sebagai suatu yang holistic dan utuh, kompleks, dinamis, penuh makna, dan hubungan gejala bersifat interaktif .

Pada penelitian ini lebih memfokuskan pada penelitian yang bersifat sekunder. Data sekunder adalah data yang diperoleh dari hasil tulisan, ulasan dan kritik terkait dengan sub kategori yaitu financial technologi, inclusif financial, EMKM, dan Covid-19. Metode penelitian merupakan suatu proses, prinsip, dan prosedur yang digunakan seorang peneliti untuk mendekati problem dan mencari pemecahan sesuatu (Mulyana, 2006 dalam Taufiq, 2020). Pendekatan penelitian yang dilakukan adalah penelitian kepustakaan, merupakan penelitian 
yang penemuannya didapatkan dengan mencari data dari berbagai literatur dan referensi yang berhubungan dengan materi pembahasan. Maka dari itu penelitian mewujudkan akuntabilitas keuangan desa melalui transparansi berbasis maqashid syariah menggunakan metode review dokumen.

Teknik pengumpulan data pada penelitian ini adalah dengan melakukan penelitian terhadap berbagai literatur yang dilakukan untuk mencari konsep yang memiliki relevansi dengan topik pembahasan melalui pengkajian buku-buku, jurnal, majalah, sera pendapat para ahli secara tidak langsung. Sedangkan instrumen penelitian adalah alat bantu yang digunakan dalam metode pengambilan data oleh peneliti untuk menganalisa hasil penelitian yang dilakukan pada langka penelitian selanjutnya. Dalam penelitian kualitatif instrumen penelitian adalah peneliti itu sendiri. Peneliti mencari dan mengumpulkan informasi yang relavan dengan penelitian dari berbagai sumber, sepeti narasumber, jurnal penelitian, artikel, buku, internet dan sumber-sumber referensi lain yang terpercaya. Maka dari itu instrumen yang digunakan dalam penelitian ini adalah peneliti itu sendiri yang mencari dan mengumpulkan data dan informasi dari jurnal-jurnal penelitian atau dengan kata lai melakukan studi pustaka.

Menurut Miles dan Huberman (1992) analisis data dan pengumpula data dilakukan melalui proses-proses yang dapat dijelaskan ketahap berikut: 1) pengumpulan data, dilakukan dengan memperoleh data yang kurang dengan studi pustaka (library research); 2) Reduksi data, dilakukan dengan cara memfokuskan perhatian dan pencarian materi penelitian dari berbagai literatur yang digunakan sesuai dengan pokok masalah; 3) Penyajian data merupakan informasi yang tersusun untuk mendapatkan pemahaman tentang apa yang diamati dan apa ya ng selanjutnya harus dilakukan; 4) Dalam penarikan kesimpulan, peneliti mencari makna dari setiap gejala yang diperoleh dalam proses penelitian, mencatat keterbatasan yang dihadapi dalam penelitian ini dan implikasi positif yang diharapkan bisa diperoleh dari penelitian ini.

Keabsahan data penelitian kualitatif dilakukan dengan melalui empat uji, yaitu credibility (validitas internal), transferbility (validitas eksternal), dependability (reliabilitas), dan confirmability (objektivitas). Berdasarkan empat jenis ujiyang telah disebutkan, penelitian ini hanya menggunakan uji yang paling sesuai yaitu credibility (validitas internal) dan dependability (reliabilitas).

a. Credibility (Validitas Internal)

Uji validitas internal merupakan uji kebenaran data. Tingkat kredibilitas yang tinggi dapat dicapai jika para partisipan yang terlibat dalam penelitian ini memahami benar mengenai apa yang disampaikannya. Uji kredibilitas dilakukan dengan triangulasi yang dapat diartikan sebagai pengecekan data dari berbagai sumber dan waktu. Merujuk pada hal tersebut, penelitian ini menggunakan dua jenis triangulasi yaitu: (a) triangulasi sumber data yang menggali kebenaran informasi terntentu melalui berbagai metode maupun sumber data.

b. Dependability (Reliabilitas)

Uji reliabilitas menjadi pertimbangan untuk menguji keilmiahan sebuah penelitian kualitatif. Tingkat reliabilititas yang tinggi dapat dapat dicapai jika analisis data dilakukan secara terstruktur sebagai upaya dalam menginterpretasikan hasil penelitian yang baik. Hal ini dimaksudkan gara peneliti lain dapat membuat kesimpulan yang sama dalam menggunakan perspektif, data mentah, dan dokumen analisis penelitian yang sedang berlangsung. Suatu penelitian yang reliable adalah ketika orang lain dapat mereplikasi proses penelitia tersebut. Pengujian reliabilitas dilakukan oleh pembimbing terhadap keseluruhan aktivitas penelitian.

\section{HASIL DAN PEMBAHASAN}

World Health Organization (WHO) menjelaskan bahwa Coronaviruses (Cov) adalah virus yang menginfeksi sistem pernapasan. Infeksi virus ini disebut covid-19. Virus Corona menyebabkan penyakit flu biasa sampai penyakit yang lebih parah seperti Sindrom Pernafasan Timur Tengah (MERS-CoV) dan Sindrom Pernafasan Akut Parah (SARS-CoV). Virus ini menular dengan cepat dan telah menyebar ke beberapa negara, termasuk Indonesia. Seseorang dapat tertular covid-19 melalui berbagai cara, yaitu: 1) Tidak sengaja menghirup percikan ludah dari bersin atau batuk penderita covid-19; 2) Memegang mulut atau hidung tanpa mencuci tangan terlebih dulu setelah menyentuh benda yang terkena cipratan air liur penderita covid-19; 3) Kontak jarak dekat dengan penderita covid-19 misalnya bersentuhan atau berjabat tangan.

Di Indonesia, penyebaran virus ini dimulai sejak tanggal 02 Maret 2020, diduga berawal dari salah satu warga negara Indonesia yang melakukan kontak langsung dengan warga negara asing. Seiring dengan berjalannya waktu, penyebaran covid-19 telah mengalami 
peningkatan yang signifikan. Hal tersebut dapat diketahui dari data berikut. Saat ini yang sudah terinfeksi covid-19 di Indonesia sebanyak 7.775 orang dan yang dinyatakan Sembuh sebanyak 960 orang dan yang meninggal sebanyak 647 orang hal ini mengajarkan kita agar berhati-hati dalam menjaga kebersihan dan juga menaati peraturan pemerintah agar pandemi ini cepat berakhir dari negara kita Indonesia. Dan ketika kita melihat penyebaran covid-19 terbesar berada di pulau jawa terutama di daerah Surabaya dan Jakarta disini bisa kita lihat bahwa kuranya kesadaran masyarakat dalam menyikapi pandemi atau covid-19 yang terjadi sehingga masih banyak orang yang masih tidak menggunakan masker, masih berkumpul di keramain, dan tidak melakukan social distancing sehingga seharusnya pemerintah lebih tegas lagi dalam menangani masyarakat yang belum mempunyai kesadaran, dan perlunya kesadaran bersama tersebut untuk memutus penyebaran covid-19 agar dapat segera berakhir dan kehidupan kita dapat berjalan seperti biasa lagi.

Entitas Mikro Kecil dan Menengah (EMKM) menjadi salah satu sektor usaha yang terdapmpak pandemi covid-19. Ini tentu saja akan berpengaruh secara langsung terhadap perekonomian indonesia, mengingat $99.9 \%$ (64,1 juta) dari jumlah unit usaha di Indonesia adalah EMKM, 97\% (116,9 juta) dari jumlah tenaga kerja di Indonesia terserap di EMKM, sekitar 61,07\% (8.573.895 miliar) dari PDB Indonesia adalah bersumber dari EMKM, sebesar 14,37\% (293.840 miliar) dari jumlah ekspor non migas Indonesia adalah berasal dari EMKM, dan sebesar $60,42 \%$ (2.564.549 miliar) dari jumlah investasi di Indonesia adalah berasal dari EMKM (Dewi, 2020). Berkaca dari hal diatas, maka EMKM mengambil peran yang begitu besar dan berarti bagi perkembangan perekonomian Indonesia. Sehingga ketika EMKM menghadapi suatu persoalan maka berdampak pada ikut terguncangnya kondisi perekonomian.

Pengertian entitas mikro kecil dan menengah (EMKM) mengacu pada Standar Akuntansi Keuangan Entitas Mikro Kecil Menengah (SAK EMKM) serta Undang-Undang Republik Indonesia No. 20 tahun 2008. Penggunaan istilah entitas pada SAK EMKM merujuk pada pengertian bahwa entitas merupakan suatu yang berwujud dan memiliki keharusan untuk membuat laporan keuangan (Hetika, 2018). Berdasarkan Undang-Undang Republik Indonesia No. 20 BAB I pasal 1 EMKM atau yang lebih sering disebut EMKM adalah usaha ekonomi produktif milik orangperseorangan dan/atau bahan usaha perorangan yang bukan merupakan anak perusahaan atau bukan cabang perusahaan yang dimiliki, dikuasai, atau menjadi bagian baik langsung maupun tidak langsung dari usaha menengah atau usaha yang memenuhi kriteria usaha kecil (Ningtas, 2017).

1) Kriteria usaha mikro adalah memiliki kekayaan bersih paling banyak $R p 50.000 .000$,(lima puluh juta rupiah) tidak termasuk tanah dan bangunan tempat usaha atau memiliki hasil penjualan tahunan paling banyak Rp 300.000.000,- (tiga ratus juta rupiah)

2) Kriteria usaha kecil adalah memiliki kekayaan bersih lebih dari Rp 50.000.000,- (lima puluh juta rupiah) sampai dengan paling banyak Rp 500.000.000,- (lima ratus juta rupiah) tidak termasuk tanah dan bangunan tempat usaha atau memiliki hasil penjualan tahunan lebih dari Rp 300.000.000,- (tiga ratus juta rupiah) sampai dengan paling banyak Rp 2.500.000.000 (dua milyar lima ratus juta rupiah).

3) Kriteria Usaha Menengah adalah memiliki kekayaan bersih lebih dari Rp 500.000.000,(lima ratus juta rupiah) sampai dengan paling banyak Rp 10.000.000.000,- (sepuluh milyar rupiah) tidak termasuk tanah dan bangunan tempat usaha atau memiliki hasilpenjualan tahunan lebih dari Rp 2.500.000.000 (dua milyar lima ratus juta rupiah) sampai dengan paling banyak Rp 50.000.000.000,- (lima puluh milyar rupiah).

Berdasarkan uraian di mengenai kriteria EMKM di atas, maka kriteria EMKM secara sederhana agar lebih mudah untuk dipahami dapat digambarkan dalam tabel berikut:

Tabel kriteria EMKM

\begin{tabular}{|c|c|c|}
\hline Entitas & Kriteria Aset & Kriteria Omzet/thn \\
\hline Mikro & Maksimal $50 \mathrm{Jt}$ & Maksimal $300 \mathrm{Jt}$ \\
\hline Kecil & $>50 \mathrm{jt}-500 \mathrm{Jt}$ & $>300 \mathrm{Jt}-2,5 \mathrm{M}$ \\
\hline Menengah & $>500 \mathrm{jt}-10 \mathrm{M}$ & $>2,5 \mathrm{M}-50 \mathrm{M}$ \\
\hline
\end{tabular}

Menurut Hilmawati, 2021 bahwa keberlanjutan usaha (business sustainability) suatu UMKM dapat diketahui dengan melihat tingkat keberhasilan suatu bisnis dalam melakukan 
inovasi, mewujudkan kesejahteraan karyawan dan pelanggan, dan mengenai return on equity bisnisnya. Akan tetapi dalam (Fajar dan Lestari, 2021) dijelaskan bahwa dibalik peran penting yang dimiliki EMKM terdapat sederet permasalahan krusial yang dihadapi EMKM dalam mempertahankan dan mengembangkan usahanya. Permasalahan tersebut diantaranya adalah:

1) Permodalan

EMKM masih menghadapi kendala dalam penambahan modal kerja baik untuk pembiayaan atau pendanaan maupun untuk investasi. Pemerintah telah mewajibkan kepada pihak bank untuk memberikan Kredit Usaha Rakyat (KUR) untuk membantu permodalan. Akan tetapi plafon KUR Mikro yang diberikan masih sangat rendah yaitu maksimal Rp 5 juta. Hal lain yang dikeluhkan EMKM saat pengajuan peminjaman selain dari keterbatasan plafon kredit adalah proses pengajuan yang cukup rumit dan jangka waktu pelunasan. Pihak perbankan juga sepertinya masih enggan memberikan kredit untuk EMKM. Hal tersebut mungkin juga disebabkan karena kredibilitas usaha yang dimiliki EMKM kurang memadai. EMKM kurang mampu dalam membuat business plan, pembukuan, dan laporan keuangan. Sedangkan penyediaan laporan keuangan bagi usaha kecil diperlukan untuk akses subsidi pemerintah dan akses tambahan modal dari kreditur.

2) Kesulitan Pemasaran

Kesulitan dalam masalah permodalan membawa masalah selanjutnya yaitu kesulitan dalam pemasaran. Pengusaha kecil tidak dapat memasarkan produknya melalui media massa dengan jangkauan yang luas. Kurangnya media promosi menyebabkan penjualan berkurang.

3) Keterbatasan Sumber daya manusia

Masih rendahnya kualitas sumber daya manusia (SDM) dalam EMKM tercermin dalam ketidakmampuan dalam pembuatan laporan keuangan, pembukuan, media promosi, identitas usaha serta profil usaha yang relevan dengan era ekonomi digital saat ini. Hal mendasar yang tidak dimiliki EMKM inilah yang menyebabkan EMKM sangat rentan terhadap persaingan pasar bebas.

4) Keterbatasan Bahan Baku

Oleh karena keterbatasan modal, para pengusaha kecil sering mengalami kesulitan dalam perolehan bahan baku karena terbentur oleh sedikitnya penawaran (supplier terbatas) dan harga yang mahal. Masalah lain yang dihadapi selain keterbatasan bahan baku adalah perlengkapan produksi yang tidak lengkap menyebabkan jenis dan variasi produk yang dihasilkan statis sehingga sulit bersaing di pasar.

5) Pengelolaan Keuangan

Oleh karena kemampuan SDM yang terbatas, sebagian besar EMKM belum melakukan pembuatan laporan keuangan secara rinci. Pencatatan akuntansi masih dilakukan secara manual, pembukuan dan pencatatan belum memadai. Perusahaan belum melakukan pelaporan keuangan dan tidak semua transaksi penjualan dan pembelian dibuatkan nota. Laporan keuangan tidak hanya diperlukan untuk kemudahan memperoleh kredit dari kreditur tetapi juga digunakan untuk mengetahui laba atau rugi yang sebenarnya, pengendalian aset, kewajiban serta modal dan penentuan pajak yang harus dibayar. Hal-hal tersebut pada akhirnya dapat dijadikan sebagai alat untuk pengambilan keputusan perusahaan.

6) Penggunaan teknologi

Keterbatasan SDM juga memengaruhi EMKM dalam pemanfaatan teknologi yang ada baik untuk akses terhadap jasa keuangan, pengelolaan keuangan maupun sarana promosi.

Financial technology (fintech) mengacu pada defenisi National Digial Research Cebter (NDRC) yaitu sebagai inovasi keuangan pada lingkup jasa keuangan atau financial. Fintech berasal dari istilah financial technology atau teknologi finansial. Menurut The National Digial Research Cebter (NDRC), di Dublin, Irlandia, mendefinisikan fintech sebagai "inovation infinancial services" atau " inovasi dalam layanan keuangan fintech" yang merupakan suatu inovasi pada sektor finansial yang mendapat sentuhan teknologi modern (Muzdalifa dkk, 2018). Secara sederhana fintech merupakan penggabungan antara jasa keuangan dan teknologi terkini, fintech sendiri dapat diistilahkan sebagai usaha dalam memaksimalkan teknologi mulai dari metode pembayaran, transfer, pinjaman, pengumulan hingga pengelolaan asset, untuk memperkuat, mengubah dan mempercepat berbagai bidang pelayanan keuangan yang dapat dilakukan secara cepat dan ringkas (Maulida, 2019 dalam Yudhira, 2021). 
Bank Indonesia dalam Marginingsih, 2021 memberikan definisi mengenai Financial Technology (Teknologi Finansial) yang diatur dan tertuang pada Pasal 1 Angka 1 Peraturan Bank Indonesia Nomor 19/12/PBI/2017. Tentang Penyelenggaraan financial technology menyatakan bahwa financial technology adalah pengguna teknologi dalam sistem pada bidang keuangan yang menghasilkan produk-produk layanan, teknologi, dan atau model bisnis baru serta dapat berdampak pada kondisi stabilitas moneter, stabilitas pada sistem keuangan, dan atau efisiensi, kelancaran, keamanan serta kehandalan sistem pembayaran. FinTech adalah inovasi dan pengembangan yang diharapkan dapat menyaingi strategi terkait uang konvensional dipenyampaian jasa keuangan. Ini adalah industri yang sedang berkembang yang memanfaatkan inovasi untuk meningkatkan latihan di bidang keuanganjasa. Pemanfaatan aplikasi seluler dan turunan lainnya untuk perbankan portabel, berkontribusi, mendapatkan layanan keuangan, dan cryptocurrency adalah jenis kemajuan yang berarti membuat layanan keuangan lebih tersedia untuk populasi keseluruhan. FinTech telah mengasumsikan pekerjaan yang berkembang dalam membentuk adegan keuangan dan perbankan (Jagtiani, 2017 dalam Alber 2020).

Fintech secara Global menunjukkan secara pesat fintech berkembang di berbagai sektor, mulai dari startup pembayaran, peminjaman (lending), perencanaan keuangan (personal finance), investasi ritel, pembiayaan (crowdfunding), remitansi, riset keuangan, dan lain-lain. Pelaku fintech Indonesia masih dominan berbisnis payment (43\%), pinjaman (17\%), dan sisanya berbentuk agregator, crowdfunding dan lain-lain. Fintech dengan layanan keuangan seperti crowdfunding, mobile payments, dan jasa transfer uang menyebabkan revolusi dalam bisnis startup. Dengan bisa memperoleh dana dari seluruh dunia dengan mudah, crowdfunding, bahkan dari orang yang belum pernah ditemui sekalipun fintech juga memungkinkan transfer uang secara global atau internasional. Jasa pembayaran seperti Paypal otomatis mengubah kurs mata uang, sehingga yang berada di Amerika bisa membeli barang dari Indonesia dengan mudahnya, Fintech juga memiliki peran penting dalam mengubah perilaku dan ekspektasi konsumen diantaranya dapat mengakses data dan informasi kapan saja dan dimana saja, dan menyamaratakan bisnis besar dan kecil sehingga cenderung untuk memiliki ekspektasi tinggi meski terhadap bisnis kecil yang baru dibangun (Muzdalifa dkk, 2018). Dengan adanya segudang manfaat yang diberikan dengan adanya teknologi, maka masyarakat dan segala entitas bisnis harus mampu menggunakan dan memanfaatkan teknologi yang ada semaksimal mungkin.

Bank Indonesia mengklasifikasikan fintech menjadi 4 jenis (Marginingsih, 2021), yakni:

1. Peer-to-Peer (P2P) Lending dan Crowdfunding

P2P lending dan crowdfunding, Fintech satu ini seperti marketplace finansial. Platform ini mampu mempertemukan pihak yang memerlukan dana dengan pihak yang dapat memberi dana sebagai modal ataupun investasi. Peer-to-peer lending atau P2P lending dapat pula diartikan sebagai layanan peminjaman dana pada masyarakat. Dana tersebit dapat berasal dari masyarakat itu sendiri maupun dari perusahaan yang membangun platform tersebut.

2. Manajemen Risiko Investasi

Fintech jenis ini dapat digunakan untuk melakukan pantauan pada kondisi keuangan dan juga melakukan perencanaan keuangan dengan lebih mudah dan praktis. Jenis manajemen risiko investasi yang satu ini biasanya hadir dan bisa diakses dengan menggunakan smartphone, dimana hanya perlu memberikan data-data yang dibutuhkan untuk bisa mengontrol keuangan.

3. Payment, Clearing dan Settlement

Fintech jenis ini ada beberapa startup finansial yang memberikan penyedian berupa payment gateaway atau dompet digital fintech payment gateway menghubungkan bisnis e-commerce dengan berbagai bank sehingga penjual dan pembeli dapat melakukan transaksi kedua produk tersebut masih masuk dalam kategori Fintech ini.

4. Market Aggregator Hadirya

Fintech ini mengacu pada portal yang mengumpulkan berbagai jenis informasi terkait sektor keuangan untuk disajikan kepada penggunanya. Biasanya fintech jenis ini mempunyai cakupan informasi terkait keuangan, tips, kartu kredit, dan investasi keuangan lainnya. Hadirnya Fintech jenis ini, diharapkan dapat menyerap banyak informasi sebelum melakukan pengambilan keputusan terkait keuangan. 
The Consultative Group to Assist the Poor (CGAP-GPFI) mendefinisikan keuangan inklusif adalah suatu kondisi di mana semua orang berusia kerja mampu mendapatkan akses yang efektif terhadap kredit, tabungan, sistem pembayaran dan asuransi dari seluruh penyedia layanan finansial. Akses yang efektif juga termasuk layanan yang nyaman dan bertanggung jawab, pada harga yang terjangkau untuk masyarakat dan berkelanjutan untuk penyedia. Diharapkan pada akhirnya, masyarakat dapat memanfaatkan layanan finansial yang formal daripada layanan finansial yang informal (Nurfalah dkk., 2019). Selain itu, Strategi Nasional Keuangan Inklusif Bank Indonesia (SNKI) mendefinisikan inklusi keuangan sebagai hak bagi setiap individu dalam mengakses dan mendapatkan layanan maksimal dari lembaga keuangan secara informatif dan tepat waktu, dengan biaya terjangkau, serta tetap memperhatikan kenyamanan dan hormat terhadap harkat dan martabatnya (Hilmawati, 2021).

Muzdalifa dkk, 2018 memaparkan mengenai visi nasional Financial Inclusif (keuangan inklusif) dirumuskan untuk mewujudkan sistem keuangan yang dapat diakses oleh seluruh lapisan masyarakat untuk mendorong pertumbuhan ekonomi, penanggulangan kemiskinan, pemerataan pendapatan, dan terciptanya stabilitas sistem keuangan di Indonesia. Adapun yng menjadi tujuan Financial Inclusif (keuangan inklusif) tersebut dijabarkan berdasarkan Peraturan Otoritas Jasa Keuangan Nomor 76/POJK.07/2016, dalam (Marginingsih 2021) setidaknya terdapat empat tujuan inklusi keuangan. Pertama, adalah untuk meningkatkan akses masyarakat pada suatu produk, lembaga atau layanan jasa keuangan. Kedua, untuk menyediakan berbagai produk atau layanan jasa keuangan PUJK (Pelaku Usaha Jasa Keuangan). Ketiga, untuk meningkatkan produk atau layanan jasa keuangan yang bisa disesuaikan dengan kemampuan dan keperluan masyarakat luas. Terakhir, untuk melakukan peningkatan kualitas produk serta layanan jasa keuangan.

Sedangkan manfaat dari inklusi keuangan menurut Bank Indonesia adalah mampu meningkatkan efisiensi ekonomi, mendukung stabilitas sistem keuangan, mengurangi terjadinya shadow banking atau irresponsible finance, mendukung pendalaman pasar keuangan, memberikan potensi pasar baru bagi perbankan, mendukung peningkatan Human Development Index (HDI) Indonesia, berkontribusi positif terhadap tingkat pertumbuhan ekonomi lokal dan nasional yang berkelanjutan, dan mengurangi tingkat kesenjangan dan rigiditas low income trap sehingga dapat meningkatkan kesejahteraan masyarakat yang pada akhirnya berujung pada penurunan tingkat kemiskinan.

Pandemic covid 19 yang di pandang dari sisi lain yaitu mampu mempercepat proses perkembangan fintech di tanah air dan membantu pemulihan sektor ekonomi yang secara tidak sengaja dipandang lebih aman karena kurangnya kontak langsung sehingga meminimalisasi penyebaran virus covid-19. Penggunaan internet tumbuh secara eksponensial, yaitu sebesar 40\% akibat pandemi covid-19. Financial technology dapat mempercepat inklusi keuangan karena financial technology membuka akses yang lebih besar ke layanan keuangan (Yudhira 2021). Krisis bukanlah waktu untuk mencoba menerapkan teknologi baru dan solusi digital sepenuhnya, tetapi inilah saatnya untuk menggunakan infrastruktur digital yang ada untuk halhal yang lebih besar dan baru potensi. Dengan demikian program-program tersebut disesuaikan dengan kondisi saat ini, merumuskan kembali potensi, yang mana adalah peluang dan tantangan. Hal tersebut kemudian diwujudkan dalam kegiatan terbaru untuk mempertahankan atau bahkan meningkatkan pertunjukan. Apalagi layanan keuangan telah difasilitasi oleh Pemerintah dengan berbagai kebijakan yang mendukung mereka (Arner, 2020 dalam Tripalupi, 2020).

Pada tahun 2019, terdapat 175,4 juta pengguna internet dan diantara nya sebesar 160 juta pengguna merupakan pengguna media sosial aktif, dan $80 \%$ dari mereka mengakses internet melalui ponsel. Peningkatan jumlah pengguna smartphone berkontribusi signifikan terhadap adopsi financial technology (CCAF, ADBI, FinTechSpace) (Yudhira 2021). Hal ini dibuktikan dengan penjualan platform belanja online per Mei 2020 meningkat 30\% dan pembayaran fintech serta pinjaman melonjak menjadi $100 \%$. Pertumbuhan total pendanaan untuk aset fintech pada tahun 2019 sebesar Rp3.306 triliun. Per April 2020 aset pendanaan fintech meningkat 9,35\% dari akhir tahun 2019, sebesar Rp3,615 triliun. Hal ini menunjukkan bahwa meskipun terkena dampak pandemi, Pertumbuhan fintech di masa pandemi covid-19 relatif stabil (Tipalupi, 2020). Dengan demikian penggunaan fintech dapat menjaga keberlangsungan bisnis dalam upaya pemulihan ekonomi nasional yang mengalami perlambatan akibat dari imbas meluasnya pandemi covid-19. 
Rizal, 2018 dan Dewi, 2021 menyebutkan dalam penelitianya bahwa fintech memiliki peran yang cukup penting bagi UMKM di antaranya adalah Mempermudah transaksi jarak jauh dengan melakukan pembayaran online yang dapat dilakukan dalam hitungan detik saja sehingga lebh efisien dan ekonomis namun tetap efektif. Fintech di Indonesia sudah diakomodir oleh Peraturan Otoritas Jasa Keuangan Nomor 77/POJK.01/2016 tentang layanan pinjam meminjam uang yang berbasis teknologi informasi. Dengan demikian telah tercipta kepastian hukum dan rasa aman bagi investor maupun para pencari dana. Penelitian (Winarto, 2020) menjelaskan bahwa peran fintech terhadap terwujudnya inklusi keuangan EMKM terdiri dari:

1) Fintech memberikan kemudahan mengakses berbagai jenis layanan keuangan. Kemudahan ini dikarenakan ada berbagai macam aplikasi fintech saat ini yang mudah terinstall di ponsel para pelaku EMKM;

2) Mampu menjangkau seluruh EMKM hingga daerah yang terpencil. Menurut banyak EMKM bahwa area domisili bukan lagi menjadi alasan untuk sulit mendapatkan akses keuangan karena yang penting ada gadget dan akses internet;

3) Fintech sudah membuka akses pembiayaan usaha yang lebih mudah dan cepat. Dalam penelitiannya menjelaskan bahwa fintech menjadi kontribusi terbesar dalam peningkatan inklusi keuangan dari segi akses pembiayaan bagi EMKM yang belum trelayani sebelumnya oelh bank. Akses pembiayaan untuk EMKM kurang dari 4 hari sudah mendapatkan pencairan dananya. Hal tersebut membantu EMKM dalam hal permodalan. Pinjaman online menawarkan tingkat bunga dan biaya yang lebih kompetitif berdasarkan analisis resiko kredit modern sehingga prosesnya relatif lebih mudah dan cepat;

4) Fintech berkontribusi besar dalam pemberdayaan EMKM dan ekonomi lokal dalam meningkatkan inklusi keuangan EMKM.

Keberlanjutan usaha suatu entitas bisnis maupun EMKM dapat dilihat dari seberapa besar tingkat keberhasilan suatu entitas dalam melakukan suatu inovasi, mewujudkan kesejahteraan para karyawan maupun pelanggan dan mengenai return on equity bisnisnya. (Hilmawati, 2021) menemukan bahwa adanya kemudahan dalam akses keuangan memiliki peran yang sangat signifikan terhadap proses pertumbuhan suatu EMKM apalagi dimasa pandemi seperti saat ini. Dimana, inklusi keuangan diangga memungkinkan EMKM mengembangkan usaha dan menerapkan suatu investasi yang jauh lebih produktif dengan memanfaatkan teknologi terbaru yang mampu menciptakan inovasi dan juga meningkatkan daya saing. Apabila suatu entitas tidak memiliki cukup akses terhadap layanan lembaga keuangan maka entitas tersebit memiliki peluang yang lumayan besar untuk mengalami kemerosotan dibanding dengan entitas lain yang memiliki akses terhadap layanan lembaga keuangan. Berikut ini beberapa layanan fintech bagi UMKM :

1. Pinjaman modal

Perusahaan Fintech hadir memberikan layanan pinjaman modal dengan proses pengajuan yang lebih sederhana dibandingkan lembaga keuangan konvensional seperti bank tanpa perlu menyerahkan jaminan dan cukup melengkapi beberapa persyaratan dokumen saja, layanan pinjaman online ini menjadi alternatif dari pinjaman konvensional bank atau perusahaan pinjaman lainnya. Pinjaman yang diajukan dapat cair dalam waktu relatif singkat yakni kurang dari seminggu.

2. Layanan pembayaran digital

Perusahaan fintech juga menyediakan pembayaran digital yang lebih mudah dan aman bagi pebisnis. Dengan proses pembayaran yang mudah dana aman, hal ini akan mampu menarik lebih banyak konsumen sehingga memberikan keuntungan bagi pelaku bisnis. Salah satu fintech yang menyediakan pembayaran digital adalah apolikasi Jenius yang bersinergi dengan perusahaan jasa transportasi online.

3. Layanan pengaturan keuangan

Ada beberapa aplikasi yang menawarkan layanan pengaturan keuangan. Inovasi ini bertujuan membantu pebisnis UMKM dalam mengatur keuangan perusahaan. Layanan yang diberikan meliputi pencatatan pengeluaran, pemantauan kinerja investasi, dan konsultasi keuangan tanpa dikenakan biaya.

Dibalik sederet manfaat fintech dalam meningkatkan inklusi keuangan terdapat beberapa kendala yang dihadapi dalam pengimplementasiannya bagi EMKM. Dimana kendala yang 
dihadapi terkait dengan 1) infastruktur, dimana masih banyak wilayah-wilayah di Indonesia yang masih terkendala jaringan internet atau bahkan belum tersentuh jaringan internet sama sekali; 2) sumber daya manusia (SDM), adanya keterbatasan kemampuan masyarakat pedesaan dalam mengaplikasikan financial technology yang mengakibatkan proses penyebaran financial technology menjadi terhambat; 3) hukum, dimana saat ini industri fintech berpatokan pada undang-undang hukum perdata diman belum terdapat aturan khusus terkait fintech menjadi penghambat tersebarnya fintech dikalangan luas; 4) literasi keuangan, pada umumnya fintech adalah hal yang baru bagi masyarakat pedesaan, sehingga dibutuhkan sosialisasi dan pelatiha-pelatihan terkait penerapannya.

\section{KESIMPULAN}

Pandemi covid-19 yang dua tahun belakangan ini mewabah cukup mengguncang perekonomian tanpa terkecuali sektor EMKM. Dibalik dampak negatif yang ditimbulkan, secara tidak langsung pandemi covid-19 ini berpengaruh pada peningkatan penggunaan teknologi. Pandemic covid 19 yang di pandang dari sisi lain yaitu mampu mempercepat proses perkembangan Fintech di tanah air dan membantu pemulihan sector ekonomi yang secara tidak sengaja dipandang lebih aman karena kurangnya kontak langsung sehingga meminimalisasi penyebaran virus covid -19. Financial technology dapat mempercepat inklusi keuangan karena financial technology membuka akses yang lebih besar ke layanan keuangan. fintech memiliki peran yang cukup penting bagi UMKM di antaranya adalah Mempermudah transaksi jarak jauh dengan melakukan pembayaran online yang dapat dilakukan dalam hitungan detik saja sehingga lebh efisien dan ekonomis namun tetap efektif.

Adapun peran financial technology (fintech) terhadap terwujudnya inklusi keuangan EMKM terdiri dari:

1) Fintech memberikan kemudahan mengakses berbagai jenis layanan keuangan. Kemudahan ini dikarenakan ada berbagai macam aplikasi fintech saat ini yang mudah terinstal di ponsel para pelaku EMKM;

2) Mampu menjangkau seluruh EMKM hingga daerah yang terpencil. Menurut banyak EMKM bahwa area domisili bukan lagi menjadi alasan untuk sulit mendapatkan akses keuangan karena yang penting ada gadget dan akses internet;

3) Fintech sudah membuka akses pembiayaan usaha yang lebih mudah dan cepat. Dalam penelitiannya menjelaskan bahwa fintech menjadi kontribusi terbesar dalam peningkatan inklusi keuangan dari segi akses pembiayaan bagi EMKM yang belum trelayani sebelumnya oelh bank. Akses pembiayaan untuk EMKM kurang dari 4 hari sudah mendapatkan pencairan dananya. Hal tersebut membantu EMKM dalam hal permodalan. Pinjaman online menawarkan tingkat bunga dan biaya yang lebih kompetitif berdasarkan analisis resiko kredit modern sehingga prosesnya relatif lebih mudah dan cepat;

4) Fintech berkontribusi besar dalam pemberdayaan EMKM dan ekonomi lokal dalam meningkatkan inklusi keuangan EMKM.

\section{REFERENCES}

[1] Alber, Nader., Mohamed Dabour. 2020. The Dynamic Relationship Between FinTech and Social Distancing under COVID-19 Pandemic: Digital Payments Evidence. International Journal of Economic and Finance, 12(11); 109-117.

[2] Dewi, Mia Clarissa. 2020. Pemanfaatan Teknologi Bagi UMKM Selama Pandemi Covid-19. Jurnal Mozaik, 8(2); 11-19.

[3] Fajar, Mochammad dan Cinta Widya Lestari. 2021. Peran Financial Technology (Fintech) dalam Perkembangan UMKM di Indonesia: Peluang dan Tantangan. Humanis (Humanitas,Management and Sciene Proceeding),1(2); 702-715.

[4] Hetika dan Mahmudah, Nurul. (2018). Penerapan Standar Akuntansi Entitas Mikro Kecil Dan Menengah (Sak Emkm) Dalam Menyusun Laporan Keuangan. Jurnal Bisnis Terapan, 02(01); 81104. 
[5] Hilmawati, Ninin Ruli Mei., Kusumaningtias, Rahmawati. 2021. Inklusi Keuangan Dan Literasi Keuangan Terhadap Kinerja Dan Keberlangsungan Sektor Usaha Mikro Kecil Menengah. Nominal Barometer Riset Akuntansi dan Manajemen, 10(1): 135-152.

[6] Ilham, Misbahul., Iswi Hariyani. 2020. Memahami Peran Lembaga Pembiayaan Syariah Dalam meningkatkan Aksesibilitas Keuangan UMKM Pada Masa Pandemi Covid-19. Widya Yuridika. Jurnal Hukum, 3(2); 257-270.

[7] Marginingsih, Ratnawati. 2021. Financial Technology (Fintech) dalam Inklusi Keuangan Nasional di Masa Pandemi Covid-19. Jurnal Akuntansi dan Keuangan, 8(1); 56-64.

[8] Moleong , Laxy j. 2012. Metode Penelitian Kualitatif. Bandung: PT. Remaja Rosdakarya.

[9] Mustaqim, Fahimatul Ulya dan Prasetyo D.S. 2020. Pengembangan UMKM Kota Surabaya di Era Industri 4.0 Melalui Penerapan Financial Technology.

[10] Muzdalifa, Irma., Inayah Aulia Rahma, Bella Gita Novalia. 2018. Peran Fintech Dalam Meningkatkan Keuangan Inklusif Pada UMKM di Indonesia. Jurnal Masharif al-Syariah. Jurnal Ekonomi dan Perbankan Syariah, 3(1).

[11] Nalini, Siti Nuzul Laila. 2021. Dampak Covid-19 Terhadap Usaha Mikro, Kecil dan Menengah. JESYA (Jurnal Ekonomi \& Ekonomi Syariah), 4(2); 662-669.

[12] Ningtyas, Jilma Dewi Ayu. 2017. Penyusunan Laporan Keuangan UMKM Berdasarkan Standar Akuntansi Keuangan Entitas Mikro, Kecil dan Menengah (SAK-EMKM) (Study Kasus Di UMKM Bintang Malam Pekalongan). Owner Riset dan Jurnal Akuntansi, 2(1); 11-17.

[13] Nurfalah, Irfan., Aam Slamet Rusyadiana. 2019. Digitalisasi keuangan Syariah menuju Keuangan Inklusif: Kerangka maqashid Syariah. Jurnal Ekonomi Keuangan, Perbankan dan Akuntansi, 11(1); 57-76.

[14] Sugiarti, Evy Nur., Nur Diana., Mawardi. 2019. Peran Fintech Dalam Meningkatkan Literasi Keuangan Pada Usaha Mikro Kecil Menengah di Malang. E-JRA, 8(4); 90-104.

[15] Taufiq, Andi Laela Kadriati dan Majid, Jamaluddin. 2020. Budaya Siri': Rejuvenanting of The Creative Provession Menuju Peace Governance Framework. Accounting Profession Journal (ApaJI), 2(1): 1025.

[16] Tripalupi, Ramadhani Irma., dan Prameshwara Aggahegari. 2020. The Impact of Covid-19 Pandemic: Challenges and Opportunities of Syariah Financial Technology. International Journal of Nusantara Islam, 8(1); 119-128.

[17] Winarto, W. W. A. (2020). Peran Fintech dalam Usaha Mikro Kecil dan Menengah (UMKM). Jesya (Jurnal Ekonomi \& Ekonomi Syariah), 3(1), 61-73.

[18] Yudhira, Ahmad. 2021. Analisis Perkembangan Financial Technologi (Fintech) Syariah Pada Masa Pandemi Covid-19 di Indonesia. Jurnal Ilmiah Akuntansi Keuangan \& Bisnis, 1(2);13-28. 